Article

\title{
German Winegrowers' Motives and Barriers to Convert to Organic Farming
}

\author{
Laura Siepmann $1, *(1)$ and Kimberly A. Nicholas ${ }^{2}$ \\ 1 Department of Earth Sciences, Uppsala University, 75236 Uppsala, Sweden \\ 2 Lund University Centre for Sustainability Studies, Box 170, 22100 Lund, Sweden; \\ kimberly.nicholas@lucsus.lu.se \\ * Correspondence: laura.siepmann@posteo.de
}

Received: 30 September 2018; Accepted: 6 November 2018; Published: 15 November 2018

check for updates

\begin{abstract}
Agriculture plays a crucial role in meeting the Sustainable Development Goals, with organic farming being one important potential contributor to environmental, economic, and social sustainability. Despite a national goal of $20 \%$ organic agriculture, currently only $6.2 \%$ of Germany's farmland is organic, and conversion rates are slowing down. However, one bright spot is organic viticulture in Germany, which has four times higher conversion rates, but literature on organic viticulture in Germany is scarce and it is unknown what factors contribute to its relative success. We used the largest wine regions in Germany, Pfalz and Rheinhessen, as a case study to investigate winegrowers' motives and barriers to convert to organic farming in practice. We compared our interview results with literature from throughout the European Union, analyzing the findings using the five capitals framework to assess livelihood strategies. The results indicate that the motives for organic farming most often identified in the literature and interviews are a pro-organic ideology of the farmer (human capital) and supportive social networks (social capital). Barriers to convert to organic farming were skeptical attitudes toward social networks (social capital) and doubting the environmental benefits of organic winegrowing, especially the use of copper (natural capital). Additional barriers were a farmer's ideology against organic farming (human capital), identified from the interviews, while the literature discussed financial risks, especially during the conversion periods (financial capital). In the particular case of organic wines in Pfalz and Rheinhessen, it was important to be able to tell a story around wines that stresses wine quality. We conclude that potential avenues to increase organic farming in Germany include addressing the use and environmental impacts of copper, addressing ideological barriers against organic farming, supporting the possibility to tell the story behind a wine, and increased financial support.
\end{abstract}

Keywords: five capitals framework; organic agriculture; sustainable development; viticulture

\section{Introduction}

Agriculture is currently a major driver of environmental problems, including as the leading cause of deforestation, biodiversity loss, nutrient pollution, and water use globally [1]. At the same time, agriculture has enormous potential to contribute to achieving many of the Sustainable Development Goals [2]. Meeting the challenge of feeding current and future generations while maintaining a good state of the environment is crucial for sustainable development, and organic farming can be seen as one possibility, among many, to strive for this.

Organic agriculture aims to be more environmentally sustainable through fighting pests and diseases without synthetic products, using diversification and rotation of crops, and the improvement of the soils with natural products, such as compost, and thus sees a farm as an integrated process that aims to reduce external inputs [3-5]. Moreover, in the European legislation, organic agriculture is 
defined as a form of agricultural production that protects the environment, and serves the purpose of strengthening rural development and providing society with demanded products [6]. Therefore, organic farming can be part of sustainable development, as it potentially improves not only the environmental sphere, but also the social, including well-being, and economic spheres [3].

The Federal Government of Germany defined sustainability goals in 2002, one of which (formerly goal 12.2 ) aimed for $20 \%$ organic agricultural land by 2010 . However, the aim to reach this goal by 2010 was dropped in 2017, when the goal was renamed goal 2.1.b, and it is now defined as a goal "to be reached in the next years" $[7,8]$. The share of total organic farming land in Germany amounted only to $6.2 \%$ in 2015 [8], meaning that the organic share in agricultural land would have to increase more than threefold to reach the goal, which would take 40 years to reach at the current rate of organic conversion [8]. Thus, the German government evaluates the development of organic agriculture as being too slow [9].

In contrast to this slow development in German agriculture overall, the organic wine sector in Germany has more than doubled between 2007 and 2016 to reach $8.22 \%$ of the total vineyard area [10]. Even though the overall proportion of organic vineyards is still low, the conversion rates are four times higher than those for agriculture overall, and meet the target conversion rates set by German policy targets for organic agriculture overall [10]. If this rate of conversion to organic farming could be achieved throughout agriculture in Germany, organic farming in Germany would reach its goal of $20 \%$ in 10 instead of 40 years.

Thus, the objective of this study is to investigate which motives and barriers winegrowers in Pfalz and Rheinhessen, Germany, have to convert to organic farming. We conducted a qualitative study using eight in-depth interviews with winegrowers to understand their perspective on the motives and barriers they face in considering or practicing organic viticulture. We use quotations from these interviews to illustrate their perceptions as much as possible, in order to help understand the reasons behind, and hopefully overcome, the worrying lack of progress in Germany's national goal to increase organic agriculture. Such practitioner-based perspectives are important to bridge the gaps between theory, policy, and practice. To frame the article, we use the five capitals framework. This framework, which assesses the capabilities of livelihoods, helps to cluster the motives and barriers of farmers in the region, and is applied when investigating in the following two research questions:

(1) Which motives and barriers to convert to organic farming within the European Union (E.U.) are discussed in the literature?

(2) What are the motives and barriers for organic and conventional winegrowers to convert to organic farming in Pfalz and Rheinhessen?

\section{Materials and Methods}

\subsection{Five Capitals Framework}

We based our research design on the five capitals framework, which aims to assess the capabilities of individuals, households, or communities to cope with local and global environmental challenges [11-15]. This assessment should serve the purpose of recognizing the options that individuals have through analyzing which capitals or assets they own, control, claim, or can access [15]. Bebbington [16] was the first to evaluate livelihood strategies with the help of the five capitals, which has become a widely accepted and applied concept [11]. We introduce the five capitals investigated in this study and their definitions in Table 1. 
Table 1. Definition of the five capitals, originally based on [15].

\begin{tabular}{cl}
\hline Capital & \multicolumn{1}{c}{ Definition } \\
\hline Natural & $\begin{array}{l}\text { Natural resource stocks, such as land, water, and environmental services, such as pollution sinks "in the } \\
\text { natural environment that provide environmental benefits through ecosystem services" [11]. }\end{array}$ \\
\hline Human & $\begin{array}{l}\text { Inherited or acquired features and skills concerning the productivity of labor, such as health, } \\
\text { knowledge, or skills [11,15,17,18]. }\end{array}$ \\
\hline Social & $\begin{array}{l}\text { Social relationships of the individual that are based on trust. These can be either vertical relationships, } \\
\text { such as authorities, or horizontal, for instance organizations or friends [15]. }\end{array}$ \\
\hline Financial & Economic assets, such as money or wealth, which can either consist of savings or access to loans [11,15]. \\
\hline Physical & $\begin{array}{l}\text { Supporting objects, such as infrastructure, tools, technology, or equipment, which are enhanced due to } \\
\text { economic production [11,15,18]. }\end{array}$ \\
\hline
\end{tabular}

\subsection{Literature Review}

To answer the first research question, we conducted a literature study on motives and barriers to adopt organic farming practices. As research on motives is scarce for wine farming and Germany, we focused on agriculture within the European Union, because the same legal framework is given in all countries of the E.U. Hence, we only considered studies that conducted their research at a time where the country was a member of the E.U. We included only literature starting from the year 2000, to ensure that only research that was conducted after the introduction of the European regulation on organic farming (Regulation (EEC) No. 2092/91) was considered.

For the literature study, we searched the databases Scopus (2016) and Web of Science (Thomas Reuters, 2015) for relevant search terms in the title, abstract, and keywords (Table S1: Literature analyzed in Supplementary Material). We identified search terms that were related to organic farming practices and conversion as well as for motives or related terms that were derived from our research questions, which we revised after checking the keywords from the initial literature search (Table S1: Literature analyzed in Supplementary Material). Then, we scanned all of the articles, and identified relevant articles that had a clear focus on motives and barriers for organic farming and were set within the European Union.

\subsection{Study Area and Selection Criteria}

For our empirical qualitative study, we conducted interviews and gave questionnaires to winegrowers from eight estates who met our study criteria: they were located in the wine regions Pfalz or Rheinhessen Germany (Figure 1), have vineyards over 10 ha, and sell their wine at the Swedish wine retailer Systembolaget. 

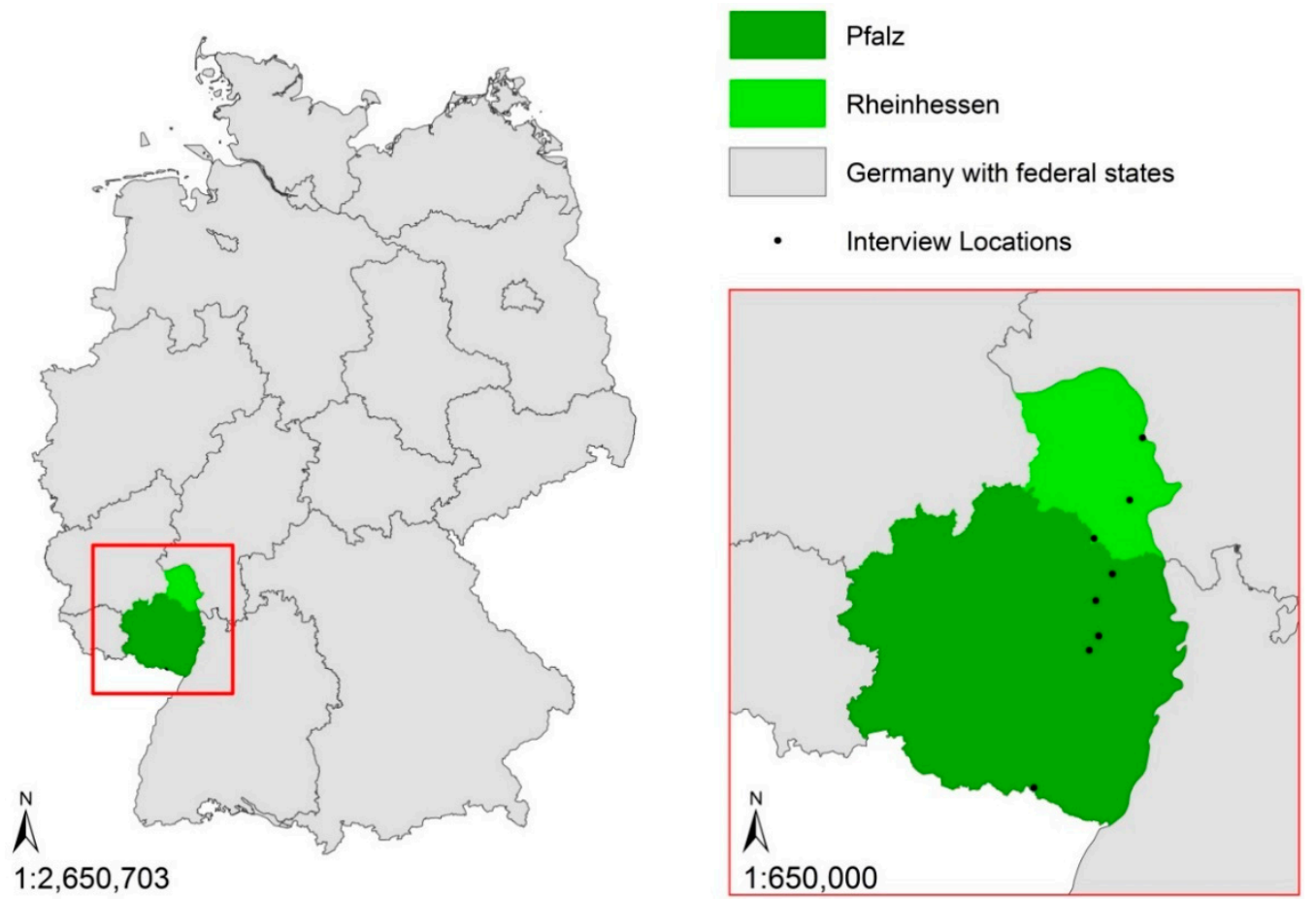

Figure 1. The study areas Pfalz (darker green) and Rheinhessen (lighter green) in Germany (gray). The black dots illustrate the location of the interviewed farms (own illustration with ArcGIS 10. Data sources: [19-21]).

We chose the regions Pfalz and Rheinhessen because they are the two largest wine regions in Germany, amounting to $49 \%$ of the German vineyard area [22], out of 13 wine regions total [23]. Pfalz and Rheinhessen belong to the federal state Rhineland-Palatinate, where $42 \%$ of all agricultural businesses produce grapes [24].

We chose the estate size of 10 ha because estates over 10 ha account for about $70 \%$ of the viticulture area in the study regions Pfalz and Rheinhessen (own calculations after 22). While nearly $85 \%$ of German vineyards are estates smaller than 10 ha [22], the estates larger than 10 ha account for $56 \%$ of the total vineyard area, and so the large vineyards make up the biggest share of the vineyard area in Germany (own calculations after 22). In Rhineland-Palatinate, the number of vineyards that belong to estates with more than 10 ha sextupled between 1979 and 2010 [25].

We chose to focus on wines sold at Systembolaget (a government monopoly and the only retailer selling alcohol in Sweden), because it is one of the biggest wine purchasers in the world (OPERAs, $2015 b$ ) and it has a large and growing focus on organic wines. To identify eligible growers, we analyzed the database of Systembolaget online, finding 129 white and 9 red German wines, both organic and conventional. Of these, 28 wineries were in the region Pfalz and Rheinhessen. We omitted cooperatives and producers without homepages, resulting in 14 remaining wineries. We posted a letter to these 14 wineries that met our criteria, with a follow-up telephone call to organize interview dates. Eight growers agreed to participate, and six did not want to participate or could not be reached after repeated attempts (57\% participation rate).

\subsection{Questionnaire and Semi-Structured Interviews}

Firstly, we sent out questionnaires to the farmers we would interview via e-mail. The questionnaire contained questions about the farmer himself as well as the estate (Table S2: Questionnaire to Farmers in Supplementary Material). Five farmers replied to the questionnaire via e-mail, one farmer filled it out by hand, and for the two who did not reply to the questionnaire, we included these questions in the interview. 
Secondly, the in-depth interviews aimed to understand why farmers converted to organic viticulture, which barriers they faced, which incentives could make conventional farmers consider converting, and what the most significant barriers were. The interviews were conducted using questions covering each of the five capitals (organic farmers could tell us especially about motives and constraints they had while converting, conventional farmers knew why they were not converting to organic farming and could tell us particularly about their doubts. We conducted seven out of eight interviews at the farms face-to-face with the interviewee, and one interview via Skype due to scheduling conflicts. The interviews took place in February 2016 and March 2016 and were conducted in German. We recorded all of the interviews and transcribed them so that they could be coded afterwards. Only the direct quotes that are presented in this paper were translated to English.

Although the study's scope exempted it from Swedish requirements for formal ethical review by an institutional review board, all procedures performed in this study involving human participants were in accordance with the ethical standards of the institution. Prior, written informed consent was obtained from all individual participants in the study.

\subsection{Categorization of Motives and Barriers from Interviews and the Literature}

For the analysis of the literature and the interview transcripts, we identified repeating concepts to define more general categories, which were then classified in the five capitals framework [26,27]. We used an iterative research strategy with both an inductive (bottom-up) approach, deriving classifications directly from the data, as well as a deductive (top-down) approach, applying established categories to classify the data. Firstly, to analyze findings in the literature, we used an inductive approach, where a category (e.g., soil protection) was formed if a concept was brought up at least in three different papers (even if under different names, e.g., erosion control, organic matter enrichment, etc.). Secondly, we used the categories that were derived from the literature to analyze the interviews (deductive approach). We also added additional categories that were derived after experience with the interviews (inductive approach), which helped focus the literature on issues of relevance for viticulture in the study area. Finally, all derived categories were described within the five capitals framework.

\section{Results}

\subsection{Literature Review}

Our literature search resulted in 101 publications that met our initial search criteria (Table S1: Literature analyzed in Supplementary Material). We used article titles to focus down to 18 publications that included motives and barriers to convert to organic farming in the E.U. (this included two studies from the non-E.U. country Norway [28,29]). We have summarized these 28 motives and barriers according to the five capitals framework in Table 2, which we describe below.

\subsubsection{Natural Capital}

The categories that could be identified in the literature in relation to natural capital dealt with the goal to strengthen the ecosystem, with soil protection often mentioned as a second aspect. Some research also discusses the influence of the farm location. The main barriers to convert to organic farming were perceived as more difficult pest and disease control and lower yields.

\subsubsection{Human Capital}

In relation to human capital, five categories of motivations to convert to organic farming could be identified in the literature: pro-organic ideology, minimizing health risk, a desire for professional challenges, a good education, as well as young farmers' age. A farmer's lack of knowledge can create a barrier to the adoption of organic farming practices. It is striking that the categories that were identified in the human capital class comprise five motives with only one barrier (Table 2). 


\subsubsection{Social Capital}

Motives that can be clustered into the social capital class are twofold: social networks can have a supportive role in converting to organic farming as well as the goal to produce high wine quality. On the other hand, a skeptical attitude towards social networks creates a barrier to converting to organic farming.

\subsubsection{Financial Capital}

Economic motives to adopt organic farming practices are of high importance, particularly a focus on higher profit, subsidies, or a premium price for products [28-30]. Some authors argue that the importance of the financial aspects is increasing [29,31]. The dominant barrier to converting to organic farming was found to be financial risks. For instance, rules of organic farming practices apply during the three-year conversion period [32]; however, a premium price cannot be claimed as products cannot be labeled as organic. Thus, income can decrease during the conversion period, which creates the main barrier to conversion [33-35].

\subsubsection{Physical Capital}

Farmers with larger farms and more diversified income sources named these as motives for organic farming, but saw tight legislation and bureaucracy as important barriers to converting to organic farming. 
Table 2. The categories identified in the five capitals divided into findings from the literature and findings from the questionnaire and interviews. They are derived from the literature if arguments according to the categories were brought up at least in 3 different papers out of the 18 reviewed. Other categories originate from the questionnaire and interviews with four organic and four conventional winegrowers in Pfalz and Rheinhessen.

\begin{tabular}{|c|c|c|c|c|c|}
\hline Category & Motive/Barrier & Definition of the Category & $\begin{array}{l}\text { Key References } \\
\text { (Literature) }\end{array}$ & $\begin{array}{c}\text { Representative Quote } \\
\text { (Questionnaire and Interviews) }\end{array}$ & Farmer Code \\
\hline \multicolumn{6}{|c|}{ Natural capital } \\
\hline $\begin{array}{l}\text { Strengthen the } \\
\text { ecosystem }\end{array}$ & motive & $\begin{array}{l}\text { The motivation for environmentally } \\
\text { sustainable farming to keep the environment } \\
\text { in a good state and an aversion against } \\
\text { chemical crop protection. }\end{array}$ & {$[28,30,31,34,36,37]$} & $\begin{array}{l}\text { "I never wanted to be the fire department in my } \\
\text { vineyards or wanted to throw something on the } \\
\text { ground that the vineyards need, but we tried rather } \\
\text { that the vineyard would take care of itself." O4 }\end{array}$ & $\mathrm{O} 2, \mathrm{O} 3, \mathrm{O} 4$ \\
\hline Soil protection & motive & $\begin{array}{l}\text { Having a healthy soil in equilibrium, in } \\
\text { good condition, and that prevents erosion. }\end{array}$ & {$[28,29,38]$} & $\begin{array}{l}\text { "Only with healthy soils can we produce good grapes } \\
\text { and from these make good wine." O2 }\end{array}$ & $\begin{array}{l}\mathrm{C} 1, \mathrm{C} 2, \mathrm{C} 3, \mathrm{C} 4, \mathrm{O} 1 \\
\mathrm{O} 2, \mathrm{O} 3, \mathrm{O} 4\end{array}$ \\
\hline Farm location & motive & $\begin{array}{l}\text { The farm location favors organic farming } \\
\text { (e.g., geographical location, difficult to } \\
\text { manage or access). }\end{array}$ & {$[31,37]$} & $\begin{array}{c}\text { Even though the climate and soil would be } \\
\text { different in Pfalz, "organic wine (... ) [would still } \\
\text { be] really feasible." O3 }\end{array}$ & $\mathrm{C} 4, \mathrm{O} 2, \mathrm{O} 3$ \\
\hline $\begin{array}{l}\text { More difficult pest } \\
\text { and disease control }\end{array}$ & barrier & $\begin{array}{l}\text { A disadvantage of organic farming in terms } \\
\text { of an increasing production risk because } \\
\text { plants cannot be treated easily and flexibly } \\
\text { with synthetic products. }\end{array}$ & {$[4,34,35,38-40]$} & $\begin{array}{l}\text { An organic farmer stressed that he had to "pay } \\
\text { dearly, [because] there were more vineyards with } \\
\text { decay than expected and you had to learn how the } \\
\text { ripeness changed after the conversion." O2 }\end{array}$ & $\begin{array}{l}\mathrm{C} 3, \mathrm{C} 4, \mathrm{O} 1, \mathrm{O} 2, \mathrm{O} 3 \\
\mathrm{O} 4\end{array}$ \\
\hline Lower yields & barrier & $\begin{array}{l}\text { A perception or concern that organic } \\
\text { farming had lower yields. }\end{array}$ & {$[4,38]$} & & \\
\hline $\begin{array}{l}\text { Amount of } \\
\text { sprayings }\end{array}$ & barrier & $\begin{array}{l}\text { The amount that vineyards have to be } \\
\text { sprayed in order to control pests } \\
\text { and diseases. }\end{array}$ & & "the possibilities to react make the difference" $\mathrm{O} 1$ & $\mathrm{C} 1, \mathrm{C} 2, \mathrm{C} 3, \mathrm{C} 4$ \\
\hline Use of copper & barrier & Copper as a measure to fight downy mildew. & & $\begin{array}{c}\text { "But in organic cultivation it [pointing to copper] is } \\
\text { not better. It sounds strange, it sounds harsh, but it } \\
\text { is not better." C3 }\end{array}$ & $\mathrm{C} 2, \mathrm{C} 3, \mathrm{C} 4, \mathrm{O} 1, \mathrm{O} 3$ \\
\hline \multicolumn{6}{|c|}{ Human capital } \\
\hline Ideology & motive & $\begin{array}{l}\text { The personal attitude towards organic } \\
\text { farming, such as the belief that organic } \\
\text { farming is better, aesthetics, living in } \\
\text { harmony with nature, } \\
\text { or environmental awareness. }\end{array}$ & {$[31,35,36,41,42]$} & $\begin{array}{l}\text { "We try to strengthen the defensive forces of the vine. } \\
\text { It is the same as what we are doing for us humans ( } \\
\ldots \text { ) in winter. It does not mean we take antibiotics } \\
\text { from November to March straight (...). We try to } \\
\text { strengthen the defensive forces of our body." O1 }\end{array}$ & $\mathrm{C} 2, \mathrm{O} 1, \mathrm{O} 3, \mathrm{O} 4$ \\
\hline $\begin{array}{l}\text { Minimizing } \\
\text { health risks }\end{array}$ & motive & $\begin{array}{l}\text { The perception that risks concerning health } \\
\text { (such as allergies) are minimized. }\end{array}$ & {$[34,40,43]$} & $\begin{array}{l}\text { To convert "was partly egoistic. (...) When we } \\
\text { worked in the vineyards and we used pesticides before, } \\
\text { everything was irritated: the arms, the hands." O4 }\end{array}$ & $\mathrm{C} 2, \mathrm{O} 3, \mathrm{O} 4$ \\
\hline
\end{tabular}


Table 2. Cont

\begin{tabular}{|c|c|c|c|c|c|}
\hline Category & Motive/Barrier & Definition of the Category & $\begin{array}{l}\text { Key References } \\
\text { (Literature) }\end{array}$ & $\begin{array}{c}\text { Representative Quote } \\
\text { (Questionnaire and Interviews) }\end{array}$ & Farmer Code \\
\hline $\begin{array}{l}\text { Desire for } \\
\text { professional } \\
\text { challenge }\end{array}$ & motive & $\begin{array}{l}\text { The personal goal to be challenged, to be } \\
\text { innovative, to be a craftsman, and to be } \\
\text { equipped with skills. }\end{array}$ & {$[28,31,38]$} & $\begin{array}{l}\text { "[The estate] has the obligation to adapt faster than } \\
\text { estates which are maybe new on the market." O3 }\end{array}$ & O1, O3 \\
\hline Well-educated & motive & $\begin{array}{l}\text { A high educational level or an education } \\
\text { outside of the agricultural field. }\end{array}$ & {$[28,31,41,43]$} & & \\
\hline Younger age & motive & $\begin{array}{l}\text { Youth as a driver to convert to } \\
\text { organic farming. }\end{array}$ & {$[28,30,35]$} & & \\
\hline Little knowledge & barrier & $\begin{array}{l}\text { A lack of knowledge as a barrier to convert } \\
\text { to organic farming. }\end{array}$ & {$[31,35,40]$} & & \\
\hline Ideology & barrier & $\begin{array}{l}\text { The ideology that organically certified } \\
\text { farming is not to be strived for. }\end{array}$ & & $\begin{array}{l}\text { Interviewer: "If you think about producing } \\
\text { organically certified wine ..." } \\
\text { Participant: "I do not do that." } \\
\text { Interviewer: "Why?" } \\
\text { Participant: "Because I think that this is } \\
\text { nonsense." C1 }\end{array}$ & $\mathrm{C} 1, \mathrm{C} 2, \mathrm{C} 3, \mathrm{C} 4, \mathrm{O} 1$ \\
\hline \multicolumn{6}{|c|}{ Social capital } \\
\hline $\begin{array}{l}\text { Supportive social } \\
\text { networks }\end{array}$ & motive & $\begin{array}{l}\text { The supportive role of social networks, such } \\
\text { as associations, family, experts, } \\
\text { policymakers, and consumers, including the } \\
\text { social acceptance and a positive image of } \\
\text { organic food. }\end{array}$ & {$[30,31,36-38,40,41,43,44]$} & $\begin{array}{l}\text { "We were the first organic business in this village. } \\
\text { We followed suit after other [estates] where we saw } \\
\text { that they achieve good results with organic [farming] } \\
\text { and now we are already six or seven estates in this } \\
\text { village." O4 }\end{array}$ & $\mathrm{C} 1, \mathrm{C} 2, \mathrm{O} 2, \mathrm{O} 4$ \\
\hline Product quality & motive & The production of high-quality products. & {$[28,31,37,40,43]$} & $\begin{array}{l}\text { "You have smaller grapes, not so much water in the } \\
\text { grapes, so you get higher quality, much more } \\
\text { concentrated wines, more intensive wines, and that is } \\
\text { fun." O4 }\end{array}$ & $\mathrm{O} 1, \mathrm{O} 2, \mathrm{O} 3, \mathrm{O} 4$ \\
\hline $\begin{array}{l}\text { Certification of } \\
\text { farming practices }\end{array}$ & motive & $\begin{array}{l}\text { The aim to validate farming practices with } \\
\text { a certification. }\end{array}$ & & $\begin{array}{c}\text { "Either we are organic, then I am certified and write } \\
\text { that on my label, or we are not, because it is a fact } \\
\text { that you have the loophole open." O3 }\end{array}$ & $\mathrm{C} 2, \mathrm{O} 1, \mathrm{O} 3$ \\
\hline Skeptical attitude & barrier & $\begin{array}{c}\text { A skeptical attitude towards social networks, } \\
\text { such as experts, advisors, employees, family, } \\
\text { or consumers. }\end{array}$ & {$[31,36,38,40,45]$} & $\begin{array}{l}\text { Some employees quit, because they had another } \\
\text { "ideological view or also another professional view, } \\
\text { because they had another opinion." O3 }\end{array}$ & $\mathrm{O} 1, \mathrm{O} 2, \mathrm{O} 4$ \\
\hline
\end{tabular}


Table 2. Cont.

\begin{tabular}{|c|c|c|c|c|c|}
\hline Category & Motive/Barrier & Definition of the Category & $\begin{array}{l}\text { Key References } \\
\text { (Literature) }\end{array}$ & $\begin{array}{c}\text { Representative Quote } \\
\text { (Questionnaire and Interviews) }\end{array}$ & Farmer Code \\
\hline \multicolumn{6}{|c|}{ Financial capital } \\
\hline Higher profit & motive & $\begin{array}{l}\text { Economic benefits and profitability or the } \\
\text { resolution of financial problems. }\end{array}$ & {$[4,29,31,34]$} & $\begin{array}{l}\text { "Of course an organic wine ( ...) is more expensive } \\
\text { than a conventionally produced one." O4 }\end{array}$ & $\mathrm{O} 1, \mathrm{O} 2, \mathrm{O} 3, \mathrm{O} 4$ \\
\hline Subsidies & motive & $\begin{array}{l}\text { Direct payments from any external } \\
\text { institution to support organic farming. }\end{array}$ & {$[30,36,44]$} & $\begin{array}{l}\text { Subsidies are "nicely meant (... ), but they have no } \\
\text { influence on the profitability of my business." O1 }\end{array}$ & $\mathrm{O} 1, \mathrm{O} 2, \mathrm{O} 3, \mathrm{O} 4$ \\
\hline Premium price & motive & $\begin{array}{l}\text { The additional financial amount a product } \\
\text { can be charged with when it is } \\
\text { organically certified. }\end{array}$ & {$[4,34,37]$} & & \\
\hline More sales & motive & $\begin{array}{l}\text { The ability to sell more products due to the } \\
\text { organic certification. }\end{array}$ & & $\begin{array}{l}\text { "It tastes good, it looks good, there is a good story } \\
\text { behind it, and that is why it is desirable." O4 }\end{array}$ & $\mathrm{O} 1, \mathrm{O} 3, \mathrm{O} 4$ \\
\hline Financial risk & barrier & $\begin{array}{l}\text { An expectation that sales will be insecure in } \\
\text { the short- or long-term and the uncertainty } \\
\text { of the market or reduced incomes during } \\
\text { conversion processes. }\end{array}$ & {$[4,28,31,34,35,37-42,46]$} & $\begin{array}{l}\text { "I do not think that that [organic certification] would } \\
\text { drive the profit. We are very satisfied with our profit } \\
\text { in our business." C3 }\end{array}$ & $\mathrm{C} 1, \mathrm{C} 3, \mathrm{C} 4$ \\
\hline \multicolumn{6}{|c|}{ Physical capital } \\
\hline Larger farms & motive & $\begin{array}{l}\text { The amount of farmland that one } \\
\text { farm manages. }\end{array}$ & {$[4,28,30,35]$} & & \\
\hline $\begin{array}{l}\text { Diversified } \\
\text { income sources }\end{array}$ & motive & $\begin{array}{l}\text { The amount of income sources and the } \\
\text { number of economic activities of a farmer. }\end{array}$ & {$[29,35,37]$} & & \\
\hline Tight legislation & barrier & $\begin{array}{l}\text { Tight, inconsistent, or changing laws related } \\
\text { to the organic certification. }\end{array}$ & {$[38,39,42]$} & "I do not want to bow to a dictate." $\mathrm{C} 1$ & $\mathrm{C} 1, \mathrm{C} 3, \mathrm{O} 2$ \\
\hline Bureaucracy & barrier & $\begin{array}{l}\text { Control systems, including paperwork, } \\
\text { controls, and distrust in institutions. }\end{array}$ & {$[4,31,34,39,45]$} & $\begin{array}{l}\text { "I do not like it, this supervision. We do not like } \\
\text { it." C1 }\end{array}$ & $\mathrm{C} 1$ \\
\hline More work & barrier & Organic farming as causing more work. & & $\begin{array}{l}\text { In an organic estate a farmer knows "there is no } \\
\text { day and no night, there is no Saturday and no } \\
\text { Sunday (...) [Spraying] goes regardless of the } \\
\text { consequences for the pressure of the employees." C4 }\end{array}$ & $\mathrm{C} 1, \mathrm{C} 2, \mathrm{C} 4, \mathrm{O} 3, \mathrm{O} 4$ \\
\hline
\end{tabular}




\subsection{Motives and Barriers for Organic and Conventional German Winegrowers}

We interviewed eight farmers, four organic (denoted O\#) and four conventional (denoted C\#) (Table 3). We have aligned their responses with those found in the literature, based on the five capitals framework, in Table 2; we briefly highlight the key responses below.

Table 3. An overview of the conventional $(\mathrm{C})$ and organic $(\mathrm{O})$ farmers that were interviewed, and their demographic information. The labels used for the farmers here $(\mathrm{C} 1, \mathrm{C} 2$, etc.) are used throughout the paper.

\begin{tabular}{|c|c|c|c|c|c|c|c|c|}
\hline Farmer & $\mathrm{C} 1$ & $\mathrm{C} 2$ & $\mathrm{C} 3$ & $\mathrm{C} 4$ & 01 & $\mathrm{O} 2$ & O3 & O4 \\
\hline Organic since & $\mathrm{n} / \mathrm{a}$ & $\mathrm{n} / \mathrm{a}$ & $\mathrm{n} / \mathrm{a}$ & $\mathrm{n} / \mathrm{a}$ & 2004 & 2005 & 2009 & 2007 \\
\hline Year born & 1948 & 1972 & 1982 & 1970 & $\mathrm{n} / \mathrm{a}$ & 1971 & $\mathrm{n} / \mathrm{a}$ & 1981 \\
\hline $\begin{array}{c}\text { Year started to work } \\
\text { on the farm }\end{array}$ & 1973 & 1990 & 2010 & 1998 & 1995 & 2008 & 2013 & 2001 \\
\hline Family business & Yes & Yes & No & Yes & Yes & No & No & Yes \\
\hline Position on the farm & Manager & Manager & Manager & Owner & Owner & Manager & Manager & Manager \\
\hline Highest education & Technical school & Technical school & Master & Master & Master & Master & Master & Technical school \\
\hline
\end{tabular}

\subsubsection{Natural Capital}

Maintaining the natural capital was the main motive behind both organic and conventional farming, mentioned by all eight farmers. Motivations to convert comprised strengthening the ecosystem, including increased climate resilience and the vine gaining a larger water supply from rooting deeper. Moreover, it deals with the goal of soil protection, including for the next generations. Finally, the farm location was a motive to convert to organic farming, which was seen as both benefitting from the conditions in Pfalz, and suffering from being one of the most northern wine-growing districts worldwide with a high degree of moisture, which makes it tough to grow grapes organically due to disease pressure.

We identified more difficult pest and disease control, more spraying, and the use of copper as barriers to converting to organic farming. Pest and disease control is a crucial aspect in monocultures, which both the organic and conventional farmers were worried about, and saw the means that were available to organic farmers to fight these threats to their crop as being limited, especially for the fungi that are the main challenge in viticulture in Germany due to high rainfall and a cool climate [47]. Secondly, all conventional farmers mentioned that organic farming requires prophylactic spraying, meaning that it has to be done more frequently than with chemical substances. With driving through the vineyards more often, more labor is needed, more greenhouse gases are emitted, and the soil becomes compressed. Thus, they questioned the sustainability of organic farming in general. Others questioned whether copper, a heavy metal that accumulates in the soil, should really be allowed as a natural spray in organic farming, where it is currently used to avoid Plasmopara viticola, the agent of downy mildew.

\subsubsection{Human Capital}

We identified three motives in the human capital to convert to certified organic farming: Firstly, the individual pro-organic ideology of the farmer is important to consider. The farmers believed that organic farming is the right thing to do, and they aimed to pass on healthy vineyards to the next generations. Secondly, minimizing health risks is a driver for some famers. With organic farming, they know what they are spraying on their vines. However, one conventional farmer had worked together with a toxicologist and discussed substances that potentially cause cancer that he did not use anymore. Finally, a desire for a professional challenge motivated some famers to convert to organic farming, as they want to be modern and progressive to drive the other farmers in their business. Professional challenge describes the personal aim of a farmer to be challenged in his or her job with more demanding tasks, with being in a leading position in the market, or with the necessity to learn new skills. One farmer had the aim to show how well-organized and structured an organic farm could be as he felt they were known as chaotic and laissez-faire. 
At the same time, the only barrier against organic farming that was found was an ideology against the values of organic farming. Two farmers did not see any benefit to organically certified farming and were not willing to consider it at all. All conventional farmers elaborated on their environmentally sustainable farming practices, which ranged from mulching to a decreased use of fertilizer, so they believed they would not need a certification. One farmer (C2) was convinced that synthetic pesticides are no longer the main problem, but rather greenhouse gas emissions, which would not be solved through an organic certification.

\subsubsection{Social Capital}

Three categories related to social capital dominated the discussion about motives to convert to organic farming: Firstly, supportive social networks, such as associations and the direct contacts that guided farmers through the process of certification, were mentioned as good examples. However, while social networks are important, the personal ideology is still more important, as some farmers disagreed with the opinions of important associations. Secondly, organic farmers expected higher wine quality based on a more clearly expressed terroir, as they found that organic vines root deeper due to a lack of fertilizer on the surface. Terroir is a highly prized but contested concept in winegrowing; it is a notion of wine quality that takes climate, cultivar, and soil into account $[48,49]$. Thirdly, the certification of farming practices is important, as farmers want to be able to point out the guidelines they are following to validate their work. Two farmers argued that a certification is not only a marketing instrument but also a statement. However, four farmers told us that the certification itself is not key to an environmentally sustainable way of farming.

However, a skeptical attitude towards social networks can also present a barrier to converting to organic farming, such as when employees quit because they have contradicting views on organic farming.

\subsubsection{Financial Capital}

We found that, for the farmers we interviewed, financial motives were not as important to motivate the conversion to organic certified wine production. In contrast, the financial risk of decreasing profits presented a main barrier to conversion for conventional farmers. The three dominant motives that were discussed are as follows. Firstly, higher profits where organic farmers were convinced that their profits had increased in the last five years. However, they explained this increase as being due to other aspects besides the organic certification. Furthermore, while cheaper wines can command a premium price for organic certified products, this is not the case in premium wines. Secondly, subsidies are seen as being too low to be relevant, whereas with the same price and quality, organic wines lead to more sales. Nevertheless, farmers saw the story of the wines as being more important.

On the other hand, three conventional farmers expected financial risks if they produced organically certified wine, due to higher production costs that would not be covered by subsidies or premium prices. They mentioned that discount stores have been selling organic products, which beat down the price.

\subsubsection{Physical Capital}

German winegrowers did not express any motives to convert to organic farming that were related to physical capital, such as farm size or the number of income sources. In this study, the farms were all comparable in size, and, for all, wine was the only source of income, so these motives were perhaps not relevant for explaining differences in this study, though they may be important in other cases.

The main barriers identified in the physical capital were, firstly, tight legislation, as the limitations regarding sprayings and the use of sulfites were seen as too harsh. One farmer worried that certification might not last through harsh regulations, which was a main barrier for him to aspire to an organic certification. Secondly, bureaucracy causes heavy paperwork, and one farmer did not want to be 
under this pressure. Finally, some farmers argued that organic farming causes more work, and they wanted to have more leisure time.

\section{Discussion}

\subsection{Comparing Motives and Barriers from the Literature and the Interviews}

Both findings from the literature and the interviews share the view that the motive to protect the soil is an important aspect of the natural capital to consider. Although the literature seems to take for granted the idea that organic farming is more sustainable, findings from our interviews show that some farmers doubt the overall sustainability of organic wine farming, especially when it comes to the use of copper.

Moreover, the literature highlights lower yields as an important barrier to converting to organic farming (natural capital), which we found to be an indirect motive in our interviews, where lower yields can be viewed as a way to increase the quality of the wine (social capital), with higher prices offsetting a loss in quantity.

Pro-organic ideology (human capital) plays an important role in the literature, and our interviews identified a clear ideology in favor of organic farming from all organic farmers. This could be due to the fact that it is a marketing strategy of the interviewed winegrowers to sell a story and place their wine in a context. Thus, the motivation of a farmer himself with his ideology is stressed more for wine than in other farming sectors, where the story around a product is not stressed and the product stands for itself without knowing who the farmer that produced it is.

In contrast, we also identified an ideology against organic farming in our interviews with conventional farmers, whereas some of the literature indicates that ideologies against organic farming hardly exist [38]. A study on viticulture in Austria [42] is in line with our interview findings that there are ideological constraints to converting to organic wine farming.

Within social capital, the supporting role of social networks is acknowledged as a motive to convert to organic farming in both the literature and our interviews. Similarly, social networks can also create a barrier to converting to organic farming if close friends or family are skeptical, which was discussed in both in the literature and our interviews.

The motives in financial capital seem to be more important for converting to organic farming in the literature than in our interviews, where economic incentives were important to support the decision to convert to organic farming, but were not the driving factor in cases where the ideology was more important. This again links to the importance of story in selling wine, where trust in the product is crucial for consumers to choose it [50]. Critical voices argue that maximizing profits is only the means to reach other goals $[31,42,51]$. However, these pragmatic financial motivations are easier to measure, and thus are often concluded to be the actual motivation.

Finally, we did not, in our interviews, identify a motive to convert to organic farming within physical capital. As discussed above, this might be due to the fact that we used a qualitative approach to understand how farmers thought about their management choices, rather than a quantitative approach to assess the physical capital of a farm.

Both the literature and our interviews stress that tight legislative frameworks and a high degree of bureaucracy are barriers to converting to organic farming. These aspects should, therefore, be looked at when trying to diminish barriers to converting to organic farming.

\subsection{Policy Recommendations for Organic Viticulture in Germany}

In order to reach the Federal Government of Germany's goal of $20 \%$ organic agricultural land, more efforts have to be put into incentivizing organic farming [8]. We now use our analysis of the motives and barriers of winegrowers in Pfalz and Rheinhessen to convert to organic farming to lay out some potential avenues for policy development for Germany to support its goal. These recommendations 
are to review the use of copper, use campaigns to promote organic farming to influence the farmers' ideology, stress the story of a product, and, finally, ensure financial profitability.

We identified the current use of copper as a fungicide in organic farming as a barrier to organic conversion, as many conventional farmers see copper and, therefore, organic agriculture as environmentally unsustainable. Research focuses currently on the more efficient use of copper as well as on alternative treatments, but a replacement for copper is yet to be found; see e.g., [52,53]. For instance, a discussion that has been taking place in the last few years is whether potassium phosphonate should be allowed in organic farming due to the fact that it can potentially reduce the need for copper [49]. The allowance of copper is currently being assessed within the legislative framework of the E.U. in order to evaluate the impact of copper salts in the soil. The negotiation process could help to find alternatives for copper or make the legislative framework more reliable if copper continues to be allowed. At the moment, the permission to use copper is only valid until 2019, causing insecurity for organic farmers on how they can fight downy mildew [54-56] and affecting the measures a farmer can take in the vineyard. However, organic pest and disease control is a broad concern, and further studies are needed in order to find practical solutions.

Furthermore, we found that all interviewed farmers saw the importance of environmental sustainability, but not all were convinced that organic agriculture was the best way to achieve it. For those who had converted to organic agriculture, a pro-organic ideology was a very important motivation, whereas an ideology against organic farming was a main barrier due to some conventional farmers' belief that they already work in the most environmentally sustainable way. Moreover, social networks interlink with the personal ideology of farmers. Addressing this ideology and beliefs against organic farming could help to promote more organic conversion. In a first step, creating the opportunity for farmers to discuss motives and barriers freely would be important. This can be done with information from official sources, or creating space for discussion among farmers. As more and more farms convert to organic farming, the discourse is likely to be increased among farmers, whereas it should be further promoted by officials. However, in a second step, public education about organic farming could be increased further to raise awareness of the concept and to increase demand for it. Moreover, social networks might help to develop a more positive view of this farming practice.

Thirdly, the story behind wines was stressed by several interviewed farmers as being crucial to their marketing strategy. Some farmers saw the organic certification as a validation of their environmentally sustainable work, and thought it would help them to communicate the high quality of their wines as, for instance, more clearly displaying terroir. Thus, the organic certification can help to promote the product, which could be stressed also in other agricultural fields. One successful example of promoting a story around a product is place of origin labels. In the European Union, there are three labels, which point out a specific designation of a place (Protected Designation of Origin, PDO), a specific place (Protected Geographical Indication, PGI), or a traditional way of producing foodstuffs (Traditional Specialty Guaranteed, TSG) [57]. This strategy of letting the customer create a relationship with a product could also be stressed for organic products.

Finally, organic farmland will only increase for large-scale adoption if it is considered to be financially profitable [58]. In Germany, the financial support system for organic farming should be revised in cooperation with the European Union to support the national goal of expanding the share of organic agricultural land. As a part of comprehensive agricultural subsidy reform, increased payments for organic production could be considered. Farmers should be involved in the process to be able to express their opinions and to gain trust in the schemes, because even organic farmers reported that subsidies are currently too low to cover the costs. Moreover, special focus should be placed on managing the conversion period, as the literature shows that some farmers expect reduced incomes or at least a high financial burden during the conversion process when adopting organic farming practices. 


\subsection{Limitations}

This paper uses the five capitals framework in the context of a highly industrialized country, rather than the more typical application in situations where people are striving for survival. We see this as a useful extension of the five capitals framework, but some may find it unfamiliar in relation to other applications. Moreover, while our eight interviewees represented more than half of the winegrowers who met our study criteria, it is still a small sample, and only representative of winegrowers in the Pfalz and Rheinhessen region who sell their wines abroad to Sweden. Therefore, more research would be needed to understand the motivations of farmers, and the barriers they face, in other regions of Germany and for other crops to convert to organic farming.

\section{Conclusions}

The objective of this paper was to identify and analyze the motives and barriers of winegrowers in Pfalz and Rheinhessen, Germany to convert to organic farming. We showed that the motives are manifold. The most important motives to convert to organic farming in the literature and the interviews were a pro-organic ideology (human capital) and supportive social networks (social capital).

The barriers, both from the literature and our interviews, focused on a skeptical attitude towards social networks (social capital). The interviews also showed that ideologies against organic farming (human capital) were a barrier to converting to it. Moreover, the literature and some farmers doubted the environmental sustainability of organic wine, especially when it comes to the use of copper (natural capital). Furthermore, the literature targets financial risks (financial capital), especially in the conversion period, as an important barrier in the conversion process.

Achieving the goal of increasing organic farming to meet Germany's 20\% target will require diminishing perceived barriers and promoting motives. Here, we have identified robust motives in favor of organic farming from both the literature and our interviews, namely a positive ideology and social networks, as well as universal barriers, namely a skeptical attitude concerning organic farming from the farmer himself or from supporting social networks. Additionally, in the case of German wine farming in Pfalz and Rheinhessen, the story behind a wine, and thus the wine's quality, is particularly important. Understanding how farmers think about organic agriculture, and incorporating these views into policy and practice, can help to increase organic farming as one of many contributions towards more sustainable agriculture.

Supplementary Materials: The following are available online at http:/ /www.mdpi.com/2071-1050/10/11/4215/ s1, Table S1: Literature analyzed; Table S2: Questionnaire to Farmers; Supplementary 3: Interview Questions.

Author Contributions: Conceptualization, L.S. and K.A.N.; Formal analysis, L.S.; Investigation, L.S.; Methodology, L.S. and K.A.N.; Supervision, K.A.N.; Validation, L.S. and K.A.N.; Writing (original draft), L.S.; Writing (review and editing), L.S. and K.A.N.

Funding: This research was conducted within the European Commission Framework Programme 7 research project OPERAs, grant agreement no. FP7-ENV-2012-308393-2. KN's time was supported by Swedish Research Council Grant \#2014-5899/E0589901.

Acknowledgments: We are very grateful to all the farmers who generously gave their time to participate in the interviews we conducted. Thanks to Lund University Libraries for 50\% support of open access publication cost.

Conflicts of Interest: The authors declare no conflict of interest. The funders had no role in the design of the study; in the collection, analyses, or interpretation of data; in the writing of the manuscript; or in the decision to publish the results.

\section{References}

1. Foley, J.A.; Ramankutty, N.; Brauman, K.A.; Cassidy, E.S.; Gerber, J.S.; Johnston, M.; Mueller, N.D.; O'Connell, C.; Ray, D.K.; West, P.C.; et al. Solutions for a cultivated planet. Nature 2011, 478, 337-342. [CrossRef] [PubMed]

2. United Nations (UN). Transforming Our World. The 2030 Agenda for Sustainable Development; A/RES/70/1; United Nations (UN): New York, NY, USA, 2015. 
3. Reganold, J.P.; Wachter, J.M. Organic agriculture in the twenty-first century. Nat. Plants 2016, 2, 15221. [CrossRef] [PubMed]

4. Best, H. Organic Farming as a Rational Choice: Empirical Investigations in Environmental Decision Making. Ration. Soc. 2009, 21, 197-224. [CrossRef]

5. Stockdale, E.A.; Lampkin, N.H.; Hovi, M.; Keatinge, R.; Lennartsson, E.; Macdonald, D.W.; Padel, S.; Tattersall, F.H.; Wolfe, M.S.; Watson, C.A. Agronomic and environmental implications of organic farming systems. Adv. Agron. 2001, 70, 261-327.

6. Council Regulation (EC). No. 834/2007 of 28 June 2007 on Organic Production and Labelling of Organic Products and Repealing Regulation (EEC) No. 2092/91; European Union: Brussels, Belgium, 2007.

7. Die Bundesregierung. Deutsche Nachhaltigkeitsstrategie: Neuauflage 2016; Die Bundesregierung: Berlin, Germany, 2017.

8. Federal Statistical Office of Germany. Umweltökonomische Gesamtrechnungen Nachhaltige Entwicklung in Deutschland: Indikatoren zu Umwelt und Ökonomie; Federal Statistical Office of Germany: Wiesbaden, Germany, 2016.

9. Federal Statistical Office. Nachhaltige Entwicklung in Deutschland: Indikatorenbericht 2014; Federal Statistical Office: Wiesbaden, Germany, 2014.

10. Bund Ökologische Lebensmittelwirtschaft (BÖLW). Zahlen, Daten, Fakten: Die Bio-Branche 2018; Bund Ökologische Lebensmittelwirtschaft (BÖLW): Berlin, Germany, 2018.

11. Dhakal, S.P. The Five Capitals Framework for Exploring the State of Friends' Groups in Perth, Western Australia: Implications for Urban Environmental Stewardship. Int. J. Environ. Cult. Econ. Soc. Sustain. 2011, 7, 135-147. [CrossRef]

12. Sayer, J.; Campbell, B.; Petheram, L.; Aldrich, M.; Perez, M.R.; Endamana, D.; Dongmo, Z.-L.N.; Defo, L.; Mariki, S.; Doggart, N.; et al. Assessing environment and development outcomes in conservation landscapes. Biodivers. Conserv. 2007, 16, 2677-2694. [CrossRef]

13. Brown, P.R.; Nelson, R.; Jacobs, B.; Kokic, P.; Tracey, J.; Ahmed, M.; DeVoil, P. Enabling natural resource managers to self-assess their adaptive capacity. Agric. Syst. 2010, 103, 562-568. [CrossRef]

14. Morse, S.; McNamara, N. Sustainable Livelihood Approach: A Critique of Theory and Practice; Springer: Dordrecht, The Netherlands, 2013.

15. Ellis, F. Rural Livelihoods and Diversity in Developing Countries; Oxford University Press: Oxford, NY, USA, 2000.

16. Bebbington, A. Capitals and Capabilities: A Framework for Analyzing Peasant Viability, Rural Livelihoods and Poverty. World Dev. 1999, 27, 2021-2044. [CrossRef]

17. Scoones, I. Sustainable Rural Livelihoods: A Framework for Analysis; IDS Working Paper No. 72; Institute for Development Studies: Sussex, UK, 1998.

18. Nelson, R.; Webb, T.; Bryon, I. Socioeconomic Data: Prioritising Collection to Support Australian Government Natural Resource Management Programs: Principles and Priorities; National Land \& Water Resources Audit: Canberra, Australia, 2006.

19. Federal Agency for Cartography and Geodesy. Verwaltungsgebiete 1:250 000: GeoBasis-DE; Federal Agency for Cartography and Geodesy: Leipzig, Germany, 2014.

20. Federal Agency for Cartography and Geodesy. Geographische Namen 1:250 000: GeoBasis-DE; Federal Agency for Cartography and Geodesy: Leipzig, Germany, 2015.

21. Statistisches Landesamt Rheinland-Pfalz; (Bad Ems, Germany). Personal communication, 2016.

22. Deutsches Weininstitut GmbH. Deutscher Wein: Statistik 2015; Deutsches Weininstitut GmbH: Mainz, Germany, 2015.

23. Bundesministeriums der Justiz und für Verbraucherschutz. Weingesetz in der Fassung der Bekanntmachung vom 18. Januar 2011 (BGBl. I S. 66), das durch Artikel 3 des Gesetzes vom 16. Januar 2016 (BGBl. I S. 52) geändert worden ist: Weingesetz. WeinG 1994; Bundesministeriums der Justiz und für Verbraucherschutz: Berlin, Germany, 2016.

24. Statistisches Landesamt Rheinland-Pfalz. Statistische Analysen: Landwirtschaftszählung 2010; Statistisches Landesamt Rheinland-Pfalz: Bad Ems, Germany, 2012.

25. Statistisches Landesamt Rheinland-Pfalz. Statistische Bände: Die Landwirtschaft 2014 mit Vergleichszahlen seit 1949; Statistisches Landesamt Rheinland-Pfalz: Bad Ems, Germany, 2015.

26. Ryan, G.W.; Bernard, H.R. Techniques to Identify Themes. Field Methods 2003, 15, 85-109. [CrossRef] 
27. Corbin, J.M.; Strauss, A.L. Basics of Qualitative Research: Techniques and Procedures for Developing Grounded Theory; SAGE: Los Angeles, CA, USA, 2015.

28. Koesling, M.; Flaten, O.; Lien, G. Factors influencing the conversion to organic farming in Norway. Int. J. Agric. Resour. Gov. Ecol. 2008, 7, 78-95. [CrossRef]

29. Flaten, O.; Lien, G.; Ebbesvik, M.; Koesling, M.; Valle, P.S. Do the new organic producers differ from the 'old guard'?: Empirical results from Norwegian dairy farming. RAF 2006, 21, 174-182. [CrossRef]

30. Kaufmann, P.; Zemeckis, R.; Skulskis, V.; Kairyte, E.; Stagl, S. The Diffusion of Organic Farming in Lithuania. J. Sustain. Agric. 2011, 35, 522-549. [CrossRef]

31. Bartulović, A.; Kozorog, M. Taking up organic farming in (pre-)Alpine Slovenia: Contrasting motivations of dairy farmers from less-favoured agricultural areas. Anthropol. Noteb. 2014, 20, 83-102.

32. Commission Regulation (EC) No. 889/2008 of 5 September 2008 Laying down Detailed Rules for the Implementation of Council Regulation (EC) No. 834/2007 on Organic Production and Labelling of Organic Products with Regard to Organic Production, Labelling and Control; European Union: Brussels, Belgium, 2008.

33. Smit, A.A.; Driessen, P.P. Conversion to Organic Dairy Production in the Netherlands: Opportunities and Constraints. Rural Sociol. 2009, 74, 383-411. [CrossRef]

34. Tranter, R.B.; Holt, G.C.; Grey, P.T. Budgetary Implications of, and Motives for, Converting to Organic Farming: Case Study Farm Business Evidence from Great Britain. Biol. Agric. Hortic. 2007, 25, 133-151. [CrossRef]

35. Tress, B. Converting to organic agriculture: Danish farmers' views and motivations. Geogr. Tidsskr.-Dan. J. Geogr. 2001, 101, 131-143. [CrossRef]

36. Läpple, D.; Kelley, H. Understanding the uptake of organic farming: Accounting for heterogeneities among Irish farmers. Ecol. Econ. 2013, 88, 11-19. [CrossRef]

37. Kallas, Z.; Serra, T.; Gil, J.M. Farmers' objectives as determinants of organic farming adoption: The case of Catalonian vineyard production. Agric. Econ. 2010, 41, 409-423. [CrossRef]

38. De Lauwere, C.C.; Drost, H.; de Buck, A.J.; Smit, A.B.; Balk-Theuws, L.W.; Buurma, J.S.; Prins, H. To Change or not to Change? Farmers' Motives to Convert to Integrated or Organic Farming (or not). Acta Hortic. 2004, 235-243. [CrossRef]

39. Sahm, H.; Sanders, J.; Nieberg, H.; Behrens, G.; Kuhnert, H.; Strohm, R.; Hamm, U. Reversion from organic to conventional agriculture: A review. Renew. Agric. Food Syst. 2013, 28, 263-275. [CrossRef]

40. König, B. Adoption of Sustainable Production Techniques: Structural and Social Determinants of the Individual Decision Making Process. Acta Hortic. 2004, 259-267. [CrossRef]

41. Mzoughi, N. Farmers adoption of integrated crop protection and organic farming: Do moral and social concerns matter? Ecol. Econ. 2011, 70, 1536-1545. [CrossRef]

42. Darnhofer, I.; Schneeberger, W.; Freyer, B. Converting or not converting to organic farming in Austria. Farmer types and their rationale. Agric. Hum. Values 2005, 22, 39-52. [CrossRef]

43. Kubala, J.; Jurczak, M.G.; Cichon, M.; Nieszporek, K. Motivations for organic farming among farmers from Malopolska Province, Poland. IJESD 2008, 7, 345. [CrossRef]

44. Rozman, Č.; Pažek, K.; Kljajić, M.; Bavec, M.; Turk, J.; Bavec, F.; Kofjač, D.; Škraba, A. The dynamic simulation of organic farming development scenarios-A case study in Slovenia. Comput. Electron. Agric. 2013, 96, 163-172. [CrossRef]

45. Madelrieux, S.; Alavoine-Mornas, F. Withdrawal from organic farming in France. Agron. Sustain. Dev. 2013, 33, 457-468. [CrossRef]

46. Smith, E.; Marsden, T. Exploring the 'limits to growth' in UK organics: Beyond the statistical image. J. Rural Stud. 2004, 20, 345-357. [CrossRef]

47. Robinson, J.; Harding, J. The Oxford Companion to Wine; Oxford University Press: Oxford, UK, 2015.

48. Van Leeuwen, C.; Friant, P.; Choné, X.; Tregoat, O.; Koundouras, S.; Dubourdieu, D. Influence of Climate, Soil, and Cultivar on Terroir. Am. J. Enol. Viticult. 2004, 55, 207-217.

49. IFOAM EU Group. EU Rules for Organic Wine Production: Background, Evaluation and Further Sector Development; IFOAM EU Group: Brussels, Belgium, 2013.

50. Bonn, M.A.; Cronin, J.J.; Cho, M. Do Environmental Sustainable Practices of Organic Wine Suppliers Affect Consumers Behavioral Intentions? The Moderating Role of Trust. Cornell Hosp. Q. 2016, 57, 21-37. [CrossRef] 
51. Bellon, S.; Lamine, C. Conversion to Organic Farming: A Multidimensional Research Object at the Crossroads of Agricultural and Social Sciences-A Review. In Sustainable Agriculture; Lichtfouse, E., Navarrete, M., Debaeke, P., Véronique, S., Alberola, C., Eds.; Springer: Dordrecht, The Netherlands, 2009; pp. 653-672.

52. Dagostin, S.; Schärer, H.-J.; Pertot, I.; Tamm, L. Are there alternatives to copper for controlling grapevine downy mildew in organic viticulture? Crop Prot. 2011, 30, 776-788. [CrossRef]

53. Kuflik, T.; Prodorutti, D.; Frizzi, A.; Gafni, Y.; Simon, S.; Pertot, I. Optimization of copper treatments in organic viticulture by using a web-based decision support system. Comput. Electron. Agric. 2009, 68, 36-43. [CrossRef]

54. Weidenauer, M. Status Report. Renewal of Approval for Copper Compounds. In Proceedings of the Second European Conference on Copper in Plant Protection, Berlin, Germany, 16-17 November 2017.

55. Regel, E.; Kauer, R.; Szolnoki, G. Öko-Weinbau Rechtlich Ausgebremst? Das Deutsche Weinmagazin 2016, 1, 32-34.

56. Berkelmann-Löhnertz, B. Bleibt Kupfer dem Weinbau Erhalten? Der Deutsche Weinbau 2016, 7, 12-14.

57. European Commission. Agriculture and Rural Development: Geographical Indications and Traditional Specialities. Available online: http:/ / ec.europa.eu/agriculture/quality/schemes/index_en.htm (accessed on 11 May 2016).

58. Crowder, D.W.; Reganold, J.P. Financial competitiveness of organic agriculture on a global scale. Proc. Natl. Acad. Sci. USA 2015, 112, 7611-7616. [CrossRef] [PubMed]

(C) 2018 by the authors. Licensee MDPI, Basel, Switzerland. This article is an open access article distributed under the terms and conditions of the Creative Commons Attribution (CC BY) license (http:/ / creativecommons.org/licenses/by/4.0/). 